\title{
Ichthyofauna of the Una river in the Paraíba do Sul Paulista River Valley, Southeastern of Brazil
}

\author{
Juliano Rodrigues Honorio ${ }^{1 *}$ \& \& Itamar Alves Martins ${ }^{2}$ \\ ${ }^{1}$ Universidade de Taubaté, Programa de Pós-Graduação em Ciências Ambientais, Estrada Municipal Dr. José \\ Luiz Cembranelli, 5000, 12081-010, Taubaté, SP, Brasil \\ ${ }^{2}$ Universidade de Taubaté, Instituto Básico de Biociências, Laboratório de Zoologia, Av. Tiradentes, 500, \\ 12030-180, Taubaté, SP, Brasil \\ *Corresponding author: Juliano Rodrigues Honorio, e-mail: julianorh0022@gmail.com
}

HONORIO, J. R., MARTINS, I. A. Ichthyofauna of the Una river in the Paraíba do Sul Paulista River Valley, Southeastern of Brazil. Biota Neotropica. 18(4): e20180528. http://dx.doi.org/10.1590/10.1590/1676-0611BN-2018-0528

\begin{abstract}
This study focus on an inventory of the ichthyofauna of the Una river, a tributary of the Paraíba do Sul river, located in the region of Paraíba do Sul River Valley, in the State of São Paulo. Sampling was carried out in three sampling areas along the channel of the Una river between April 2016 and March 2017. For the collection of fish specimens, was used angling, fyke nets, cast nets, dragnets and hand nets. A total of 1.534 specimens were collected, which corresponds to five different orders, 14 families, 26 genera and thirty species. The study revealed that the most significant number of reported species are from the orders Siluriformes and Characiformes. The Characidae family was the most representative concerning the wealth of species and Astyanax aff. bimaculatus (two spot Astyanax | lambari-do-rabo-amarelo) was the species with the highest number of individuals captured. The freshwater ichthyofauna of the Una river is composed of eight species considered allochthonous and one exotic. Of the thirty species listed in this study, five are new records for the Paraíba do Sul river basin.
\end{abstract}

Keywords: introduced species, new occurrence records, diversity, endemic species.

\section{Ictiofauna do rio Una, Vale do Paraíba do Sul Paulista, sudeste do Brasil}

Resumo: Este trabalho teve como objetivo realizar o inventário da ictiofauna do rio Una, afluente do rio Paraíba do Sul na região do Vale do Paraíba do Sul Paulista. As coletas foram realizadas em três áreas de amostragem ao longo do canal do rio Una entre os meses de abril de 2016 e março de 2017. Para a coleta dos espécimes de peixes foram utilizadas varas de pesca, covos, tarrafas, redes do tipo tela de arrasto manual e puçás. Foi coletado um total de 1.534 exemplares pertencentes a cinco ordens, 14 famílias, 26 gêneros e trinta espécies. Siluriformes e Characiformes foram as ordens com o maior número de espécies registradas. A família Characidae foi a mais representativa em relação a riqueza de espécies e Astyanax aff. bimaculatus (lambari-do-rabo-amarelo), a espécie com maior número de indivíduos capturados. A ictiofauna do rio Una apresentou em sua composição oito espécies de origem alóctone e uma exótica. Das trinta espécies listadas neste trabalho, cinco são novos registros de ocorrência para a bacia do rio Paraíba do Sul.

Palavras-chave: espécies introduzidas, novos registros de ocorrência, diversidade, espécies endêmicas.

\section{Introduction}

Estimates show that among more than 33.900 species of fish described on the planet, 13.000 exclusively inhabit freshwater environments (Nelson et al. 2016, Eschmeyer \& Fong 2017). Much of this freshwater fish species richness is found in tropical waters of the Neotropical Region, especially in the South American continent, where recent surveys indicate the presence of 5.160 valid species (Reis et al. 2016). Brazil, the largest country of Neotropics, also presents the most diverse ichthyofauna in the world, where more than 3.300 species are currently registered (Froese \& Pauly 2017). This high number of species occurs mainly because of its geographical position and size of its hydrographic network (Agostinho et al. 2007).

Among the large Brazilian hydrographic systems is the set of basins that drains the southeastern region of the country, generally called the Brazilian East (Menezes 1972). These basins are characterized by being independent, small in size and draining directly into the Atlantic Ocean (Agostinho et al. 2007). As a result of their respective geological and evolutionary histories, these basins present ichthyofaunas with high differentiation (Ribeiro 2006). One of the main basins of the Eastern Brazilian System, the Paraíba do Sul river basin, stands out for its highly endemic ichthyofauna, to the point of being considered a distinct 
ecoregion among the other regions forming this specific region of ichthyofauna (Abell et al. 2008).

Despite its intense environmental degradation, the Paraíba do Sul river basin is home to a highly diversified ichthyofauna (Teixeira et al. 2004). Currently, this basin counts for the registration of 130 species of freshwater fish, 71 of which occurring in the State of São Paulo. However, ichthyofauna surveys are not common in the basin, especially in the areas belonging to the State of São Paulo, which have not been systematically inventoried yet. Many of the hydrographic basin's smaller tributaries remain poorly studied regarding its fish species composition (Bizerril 1999, Melo et al. 2006, Oyakawa \& Menezes 2011).

The Una river, one of the most important tributaries of the Paraíba do Sul river in the State of São Paulo (Marengo \& Alves 2005), is an example of a river virtually unknown from the ichthyological point of view. In this context, the objective of the present study is to carry out the first inventory of Una river fish species, which may serve as a tool in the development of conservation strategies for this area.

\section{Material and methods}

\section{Study Area}

The Paraíba do Sul river is formed by the union of the Paraitinga river and Paraibuna river in the State of São Paulo. The Paraíba do Sul river runs a distance of just over $1.000 \mathrm{~km}$ until it drains into the Atlantic Ocean in Atafona, a city in the State of Rio de Janeiro (Hilsdorf \& Petrere Jr 2002). In addition to the territory of São Paulo, the Paraíba do Sul river basin also drains the States of Minas Gerais and Rio de Janeiro, in a total area of approximately $57.000 \mathrm{~km}^{2}$ (Bizerril 1999).

The hydrographic basin of the Una river occupies a total area of 476 $\mathrm{km}^{2}$ distributed among the territory of the cities of Taubaté, Tremembé, Pindamonhangaba and Redenção da Serra, in the Paraíba do Sul River Valley region in the State of São Paulo (Batista et al. 2005). The Una river is formed by the union of the Santa Luzia river and the Almas stream in Taubaté, crossing a distance of $36 \mathrm{~km}$ and flowing from the south to the north until its confluence with the Paraíba do Sul river in the city of Tremembé, SP. As it crosses rural districts, the river receives several tributaries, having its course adapted to the relief (Prado \& Abreu 1995) (Figure 1). If the length of its longest tributary is added, the Una river has a total length of approximately $70 \mathrm{~km}$ (Targa 2009).

The Una river runs at altitudes varying between 500 and 900 meters of elevation. The basin is limited by the mountain range of the Serra do Quebra-Cangalha, to the Northeast, and by the mountain range of the Serra do Jambeiro, to the Southwest. For this reason, the topography of the basin in its upper portion is rugged, smoothing towards its lower course (Prado \& Abreu 1995). The natural vegetation, typical of the Atlantic Forest, is currently restricted to mountainous areas, such as on the slopes of the Serra da Mantiqueira, or inside small landowners properties in the form of small natural reserves (Freitas Junior \& Marson 2007). The prevailing climate in the Una river basin is subtropical, with a dry winter and a hot and humid summer (Devide et al. 2014).

The study area of this work consists of three collecting locations, here called area I, area II and area III located along the main channel of the Una river. Area I ( $23^{\circ} 05$ ' 03.7 “' $\mathrm{S}-45^{\circ} 29^{\prime} 00.5^{\prime}$ ” W) is the upper region, located near the headwaters of the Una river, in the rural area of Taubaté. This region is characterized by the presence of riparian vegetation formed by medium to large trees and Gramineae, which are eventually submerged during the rainy season. The substratum is predominantly composed of sand, gravel, stones and plant material of allochthonous origin (Figure 2a, Figure 2b). Area II (23 01 '39.8 " $\mathrm{S}$ $45^{\circ} 30^{\prime} 24.2^{\prime} \mathrm{W}$ ) is the intermediate portion of the Una river, located in a floodplain region. There is riparian vegetation composed of small to large trees, herbaceous vegetation and grasses (Gramineae) in constant contact with water. The substratum is predominantly composed of sand

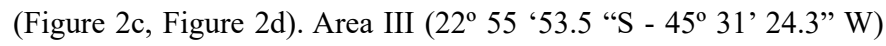
corresponds to the lower portion of the Una river, located less than six hundred meters from the confluence with the Paraíba do Sul river in Tremembé. The riparian vegetation is formed by grasses and trees from medium to large size. The substratum is formed by sand, gravel, rocks and shale (Figure 2e, Figure 2f).

\section{Fish Collecting}

Monthly sample collections were carried out between April 2016 and March 2017 in the three sampling areas within a delimited area of one hundred fifty meters each. Samples were performed by three people who spent up to four hours in each sampling area each time. Fishes were collected using angling, fyke nets (in the backwater area), and cast nets with fishnet mesh measurement varying from 0.5 to $3.0 \mathrm{~cm}$ between opposite knots. Dragging fish along the riparian vegetation with the aid of dragnets and seine nets were also used. Collection among rocky area in the riverbanks with the help of hand nets was also carried out.

The collected fish was immediately fixed in $10 \%$ formalin and then transferred to $70 \%$ ethanol solution. The specimens were identified with the use of identification keys and their status confirmed by specialist (Prof. Dr. Francisco Langeani Neto-DZSJRP). All the specimens sampled are deposited in the Coleção Científica do Laboratório de Zoologia da Universidade de Taubaté-CCLZU.

Fishes were classified in native, indigenous or autochthonous species (species which occur naturally in the basin); allochthonous species (species from different hydrographic basins within the Neotropical Region which were introduced into the Paraíba do Sul river); and exotic species (species from other continents which artificially entered the Paraíba do Sul river) (Oyakawa \& Menezes 2011).

\section{Results}

A total of 1.534 specimens of freshwater fish was collected, belonging to five orders, 14 families, 26 genera and thirty species (Table 1, Figure 3, Figure 4). The order Siluriformes (43.3\%, $n=13$ species) was predominant regarding the number of species captured, followed by Characiformes $(36.6 \%, \mathrm{n}=11$ species), Perciformes $(13.3 \%, \mathrm{n}=$ four species), Gymnotiformes $(3.4 \%, \mathrm{n}=$ one species $)$ and Synbranchiformes $(3.4 \%, \mathrm{n}=$ one species).

The most representative families were the Characidae (seven species), Loricariidae (six species) and Cichlidae (four species). Characidae was also the most representative family concerning the number of specimens collected (44.2\%), followed by the families Loricariidae (23.4\%) and Cichlidae (9\%). Astyanax aff. bimaculatus was the species with the highest number of specimens collected (37.4\%), followed by Hypostomus cf. luetkeni (12.6\%) and Corydoras nattereri (8.6\%). 


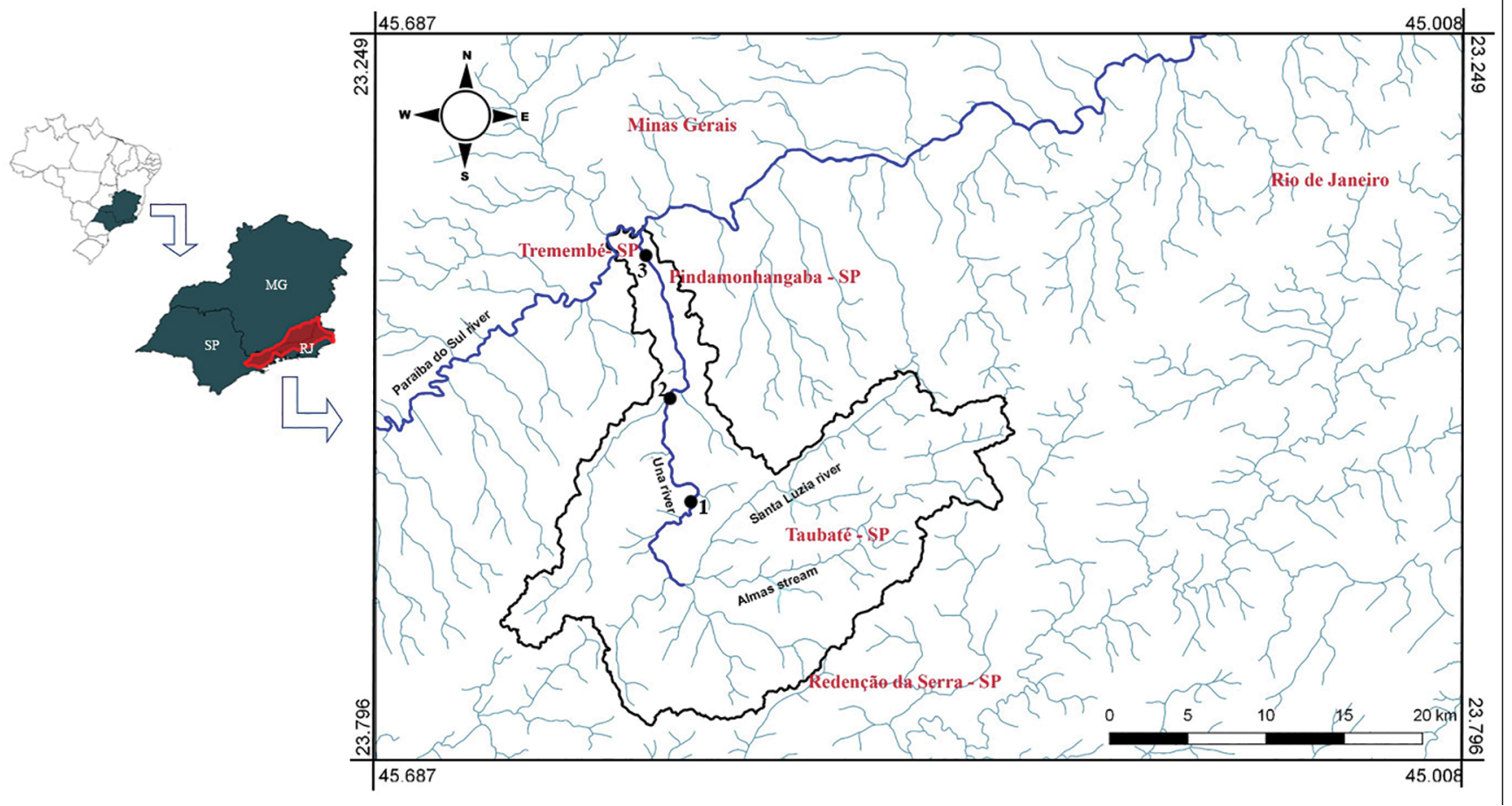

Figure 1. Hydrographic map of the Paraíba do Sul river basin encompassing the States of São Paulo (SP), Minas Gerais (MG) and Rio de Janeiro (RJ), highlighting the limits of the Una river basin, Paraíba do Sul River Valley, State of São Paulo, Brazil. Sampling areas: 1) area I: $23^{\circ} 05$ '03.7 "S - $45^{\circ} 29^{\prime}$

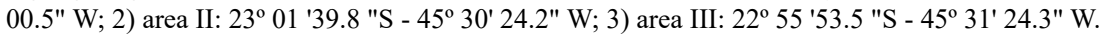

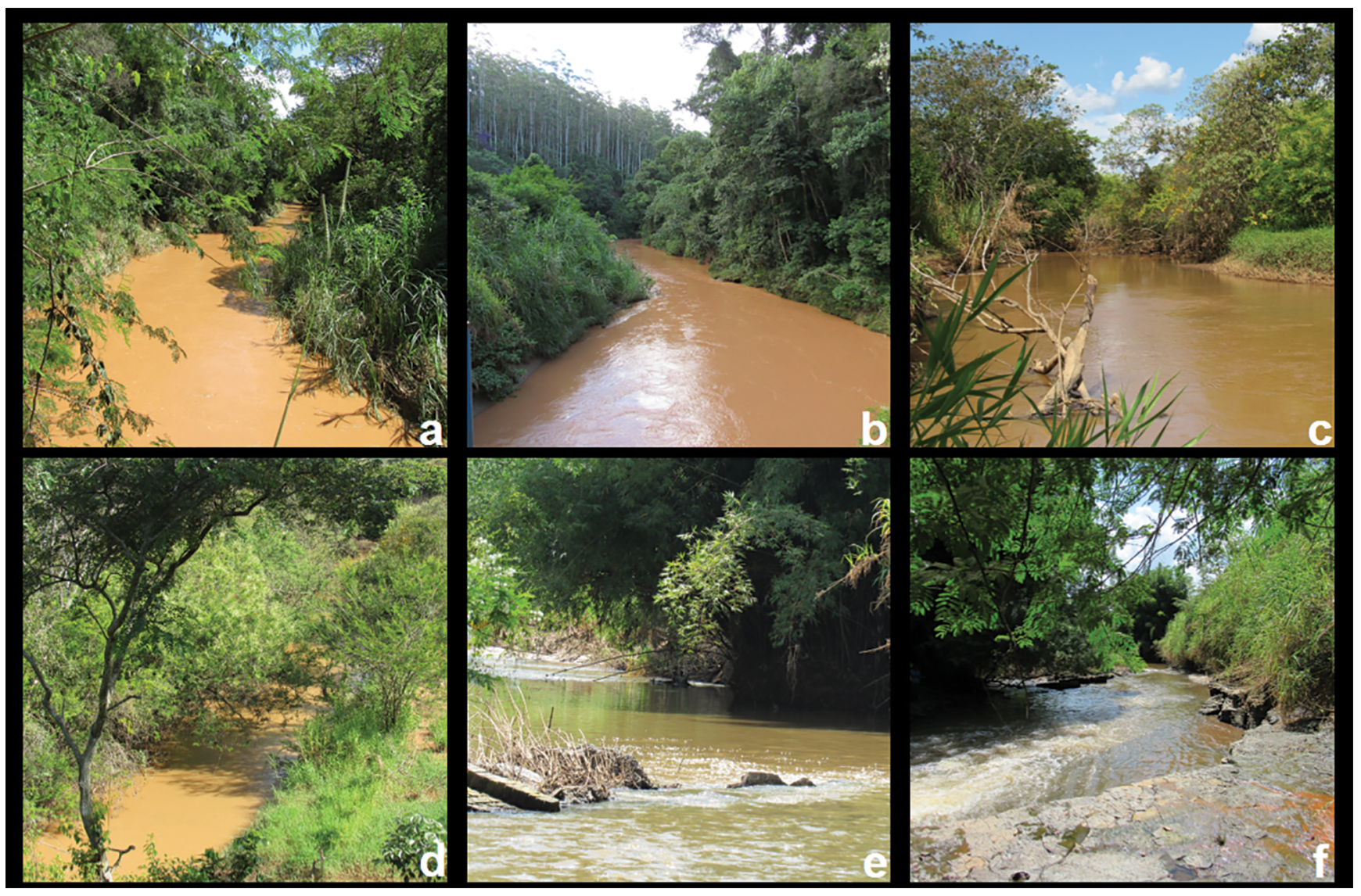

Figure 2. Overview of the three sampling areas along the Una river, in the Paraíba do Sul River Valley, in the State of São Paulo, Brazil. a-b) area I - 23ํำ $05^{\prime}$

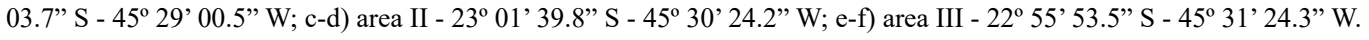


Table 1. Taxonomic list of collected species in the tree sampling areas along the Una river, Paraíba do Sul River Valley, São Paulo, in the period from April 2016 to March 2017. $(*)$ Allochthonous species, $(* *)$ exotic species.

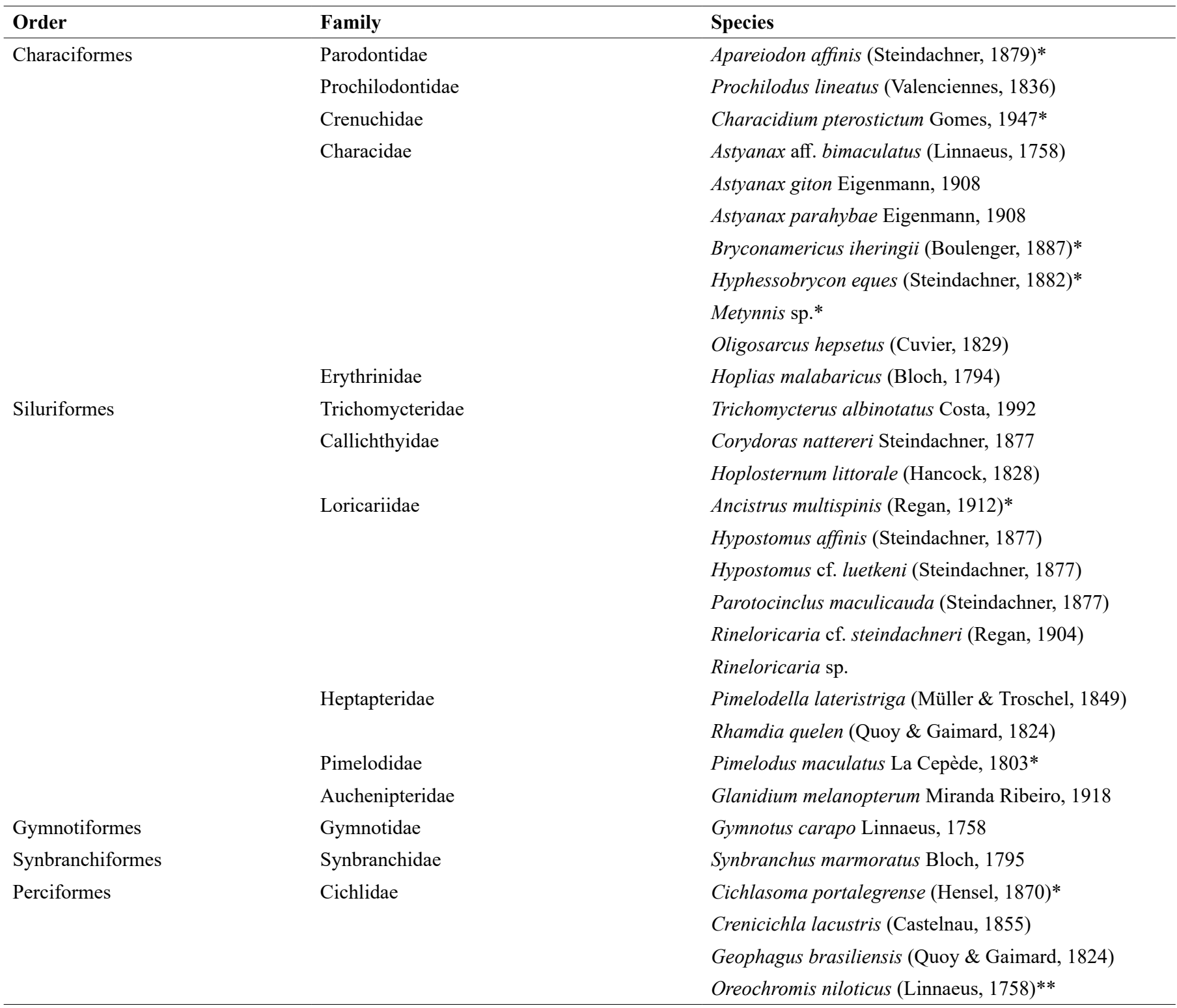

Of the thirty species recorded here, eight are considered as allochthonous: Apareiodon affinis Characidium pterostictum, Bryconamericus iheringii, Hyphessobrycon eques, Metynnis sp., Ancistrus multispinis, Pimelodus maculatus and Cichlasoma portalegrense. Apareiodon affinis, C. pterostictum, B. iheringii, A. multispinis and $C$. portalegrense also new records for the Paraíba do Sul river basin. One species was considered exotic: Oreochromis niloticus.

\section{Discussion}

The predominance of Siluriformes (catfish) and Characiformes (characins) in the composition of the ichthyofauna of the Una river corroborates the pattern of fish biodiversity and abundance of the Paraíba do Sul river basin (Bizerril 1999), the rivers of the Brazilian East (Bizerril 1994), the freshwater environments of Brazil (Buckup et al. 2007) and the Neotropical Region (Reis et al. 2016). In general, the ichthyofauna recorded in the Una river is very similar to that reported for the Paraíba do Sul river basin in the works of Bizerril (1999) and Teixeira et al. (2004). Twenty-two species listed for the Una river had previously been cited in Element Occurrence (EO) Reports produced by those authors to Paraíba do Sul river basin. Considering only the portion of this basin in the São Paulo State, Oyakawa \& Menezes (2011) registered 71 species, of which 19 species were listed in the present study.

Astyanax aff. bimaculatus was the most abundant species in the three sampling areas along the Una river. It belongs to a group of species sharing similar color pattern, composed of at least 22 valid species distributed in practically all the hydrographic basins of South America, representing, certainly, one of the most abundant morphotypes in the continent (Lucena \& Soares 2016). This freshwater fish species shows reduced size, high reproduction rate, and rapid growth. It is an opportunistic feeder, relatively unselective for zooplankton, detritus, higher plants and sometimes the scales of fish. This behavior certainly 


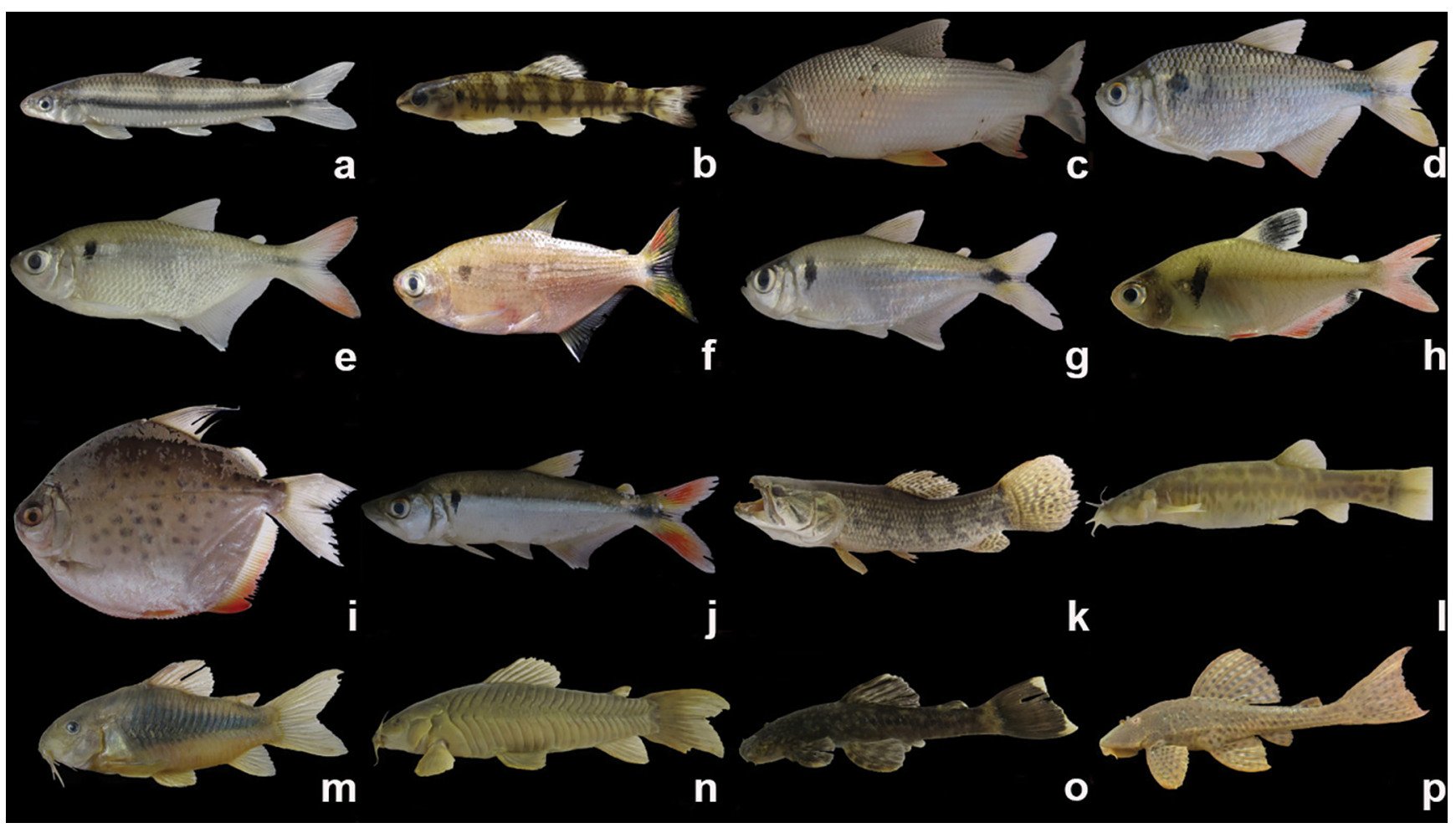

Figure 3. Registered species in the Una river in the period from April 2016 to March 2017. a) Apareiodon affinis, 39,9 mm; b) Characidium pterostictum, 46,6 mm; c) Prochilodus lineatus, 250,0 mm; d) Astyanax aff. bimaculatus, 73,4 mm; e) Astyanax giton, 72,2 mm; f) Astyanax parahybae, 82,0 mm; g) Bryconamericus iheringii, 49,1 mm; h) Hyphessobrycon eques, 28,0 mm; i) Metynnis sp., 84,9 mm; j) Oligosarcus hepsetus, 63,8 mm; k) Hoplias malabaricus, 244,1 mm; 1) Trichomycterus albinotatus, 141,3 mm; m) Corydoras nattereri, 44,4 mm; n) Hoplosternum littorale, 165,1 mm; o) Ancistrus multispinis, 73,2 $\mathrm{mm}$; p) Hypostomus affinis, 151,9 mm.

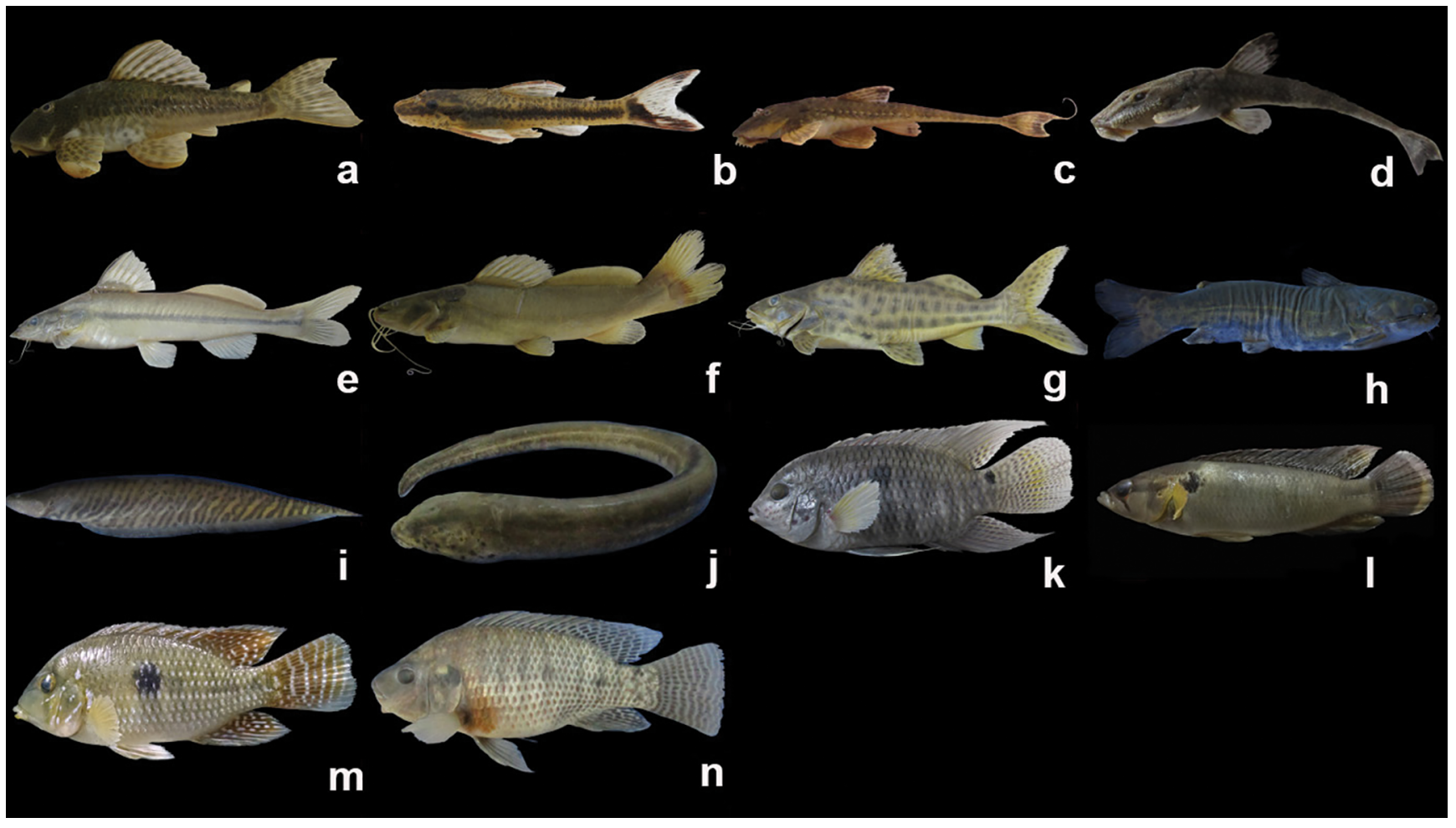

Figure 4. Registered species in the Una river in the period from April 2016 to March 2017. a) Hypostomus cf. luetkeni, 113,1 mm; b) Parotocinclus maculicauda, $31,5 \mathrm{~mm}$; c) Rineloricaria cf. steindachneri, 112,1 mm; d) Rineloricaria sp., 149,5 mm; e) Pimelodella lateristriga, 107,2 mm; f) Rhamdia quelen, 155,3 $\mathrm{mm}$;) Pimelodus maculatus, 210,5 mm; h) Glanidium melanopterum, 180,4 mm; i) Gymnotus carapo, 195,4 mm; j) Synbranchus marmoratus, 480,0 mm; k) Cichlasoma portalegrense, 100,0 mm; 1) Crenicichla lacustris, 97,1 mm; m) Geophagus brasiliensis, 121,7 mm; n) Oreochromis niloticus, 190,0 mm. 
favors its distribution in most different environments that occur (Arcifa et al. 1991, Esteves \& Galleti Jr 1995, Melo 2001, Andrian et al. 2011).

Other two abundant species recorded in this work were Heptapteridae, Pimelodella lateristriga, and the Callichthyidae, Corydoras nattereri. Astyanax aff. bimaculatus and P. lateristriga are generalist species, showing great plasticity in their foraging behavior, which favor their high incidence in the environments they inhabit (Mazzoni et al. 2010). Corydoras nattereri belongs to a group composed of freshwater fish species which withstand the stress of low oxygen levels in water. They have been known to inhabit stretches of slow water in rivers, areas where there is a higher sediment deposition rate (Reis 2003). This species showed greater abundance in the intermediate portion of Una river, located in a floodplain region, where the river presents lower current and high sediment accumulation.

Among the 19 native species of the Paraíba do Sul river basin sampled in the Una river, Corydoras nattereri and Parotocinclus maculicauda have not been formally recorded along the São Paulo portion of the basin. Their known distribution lies within tributaries located in the States of Rio de Janeiro and Minas Gerais. In this work, Bizerril (1999) mentioned the preference of C. nattereri for stretches of sediment-laden water along the final portions of the Paraíba do Sul river located in the State of Rio de Janeiro. Vieira \& Rodrigues (2010) listed the presence of $P$. maculicauda in the Muriaé river, a tributary of Paraíba do Sul river located in the State of Minas Gerais.

Among the eight allocthonous species aforementioned for the Una river, Hyphessobrycon eques, Metynnis sp. and Oreochromis niloticus are economically important. The reduced size and reddish coloration of $H$. eques make it an appreciated species in the aquarium trade. This species occurs naturally in the Amazon basin and the Paraguay river and has been introduced in the Upper Paraná river basin and the Brazilian East coastal rivers (Lima et al. 2007). The introduction of ornamental fish species into lotic ecosystems usually occurs through intentional release of specimens into freshwater bodies (Fuller et al. 1999, Semmens et al. 2004, Moraes et al. 2017). In the Paraíba do Sul river basin, this situation is aggravated by the presence of the most extensive ornamental freshwater fish aquaculture park in Brazil, located in the Minas Gerais portion of the basin (Magalhães et al. 2002).

Oreochromis niloticus is the most exploited species in freshwater fish farm cage systems in the world. This fact is mainly due to its high productivity and tolerance diverse environmental conditions (Carvalho et al. 2010). Metynnis spp. are commonly used in aquarium ornamentation. This genus is frequently cited in articles and inventories along the Paraíba do Sul river basin as allochthonous into the system (Moraes et al. 2017). In fact, according Ota (2015), there are no occurrence records of Metynnis in Southeast coastal rivers until the 1990s.

The presence of O. niloticus and Metynnis in the Paraíba do Sul river basin is attributed to irregular escapes from cage systems of freshwater fish farms. These cages are prone to allow fish to escape during floods caused by heavy rains (Orsi \& Agostinho 1999, Moraes et al. 2017). The presence of this kind of enterprise is quite common along the Una river, mainly in their medium and lower courses, located in the municipalities of Taubaté and Tremembé.
Other allochthonous species listed to the Una river, Apareiodon affinis, Characidium pterostictum, Bryconamericus iheringii, Ancistrus multispinis and Cichlasoma portalegrense are new reports records for the Paraíba do Sul river basin. Among these species, A. affinis presents the largest geographical distribution in Brazilian systems, being frequently found in the Paraná and Uruguay basins, in addition to other hydrographic systems located in well sampled regions (Godoy 1975, Pavanelli 1999, 2007). In this study, A. affinis and C. pterostictum were restricted to the final portion of the Una river, near the it confluence with Paraíba do Sul river in Tremembé. It is still not possible to point out the causes of the presence of these five species in the Una river. However, it is probable that future biogeographic analysis of the region will elucidate this issue.

The presence of a relatively high number of species from other freshwater systems is not a particular feature of the Una river but also of the Paraíba do Sul river basin, where currently there are records of more fifty non-native species (Vieira \& Rodrigues 2010). In a recent analysis, the introduction of species has been pointed out as one of the leading causes of extinction of freshwater fish species in this basin, as in lotic ecosystems in general (Bizerril 1999, Simberloff 2003).

The species list of the Una river contributes to fill part of knowledge gap regarding the fish fauna distribution in the Paraíba do Sul river basin in the State of São Paulo, by the inventory of an area unstudied until this moment, being able to serve as subsidies for the elaboration of future management actions in the Paraíba do Sul Valley region.

\section{Acknowledgements}

We would like to thank Antônio Teotonio Honorio, Neide Aparecida Honorio and Marlene Marta da Silva Honorio for their help during fieldwork; Francisco Langeani Neto (DZSJRP) for the valuable help in the identification of the specimens and all the scientific assistance given to the authors of this article. We would also like to thank Eduardo Henrique Teixeira (CCLZ/UNITAU) and Roselene Silva Costa Ferreira (DZSJRP) for assistance in laboratory work; and FAPETI (Foundation for Research, Technology and Innovation Support) for the financial support granted to this research.

\section{Author Contributions}

Juliano Rodrigues Honorio: Substantial contribution in the concept and design of the study; contribution to manuscript preparation, data collection and in the data analysis and interpretation.

Itamar Alves Martins: Contribution to manuscript preparation, data analysis and interpretation, critical revision and in the adding to intellectual content.

\section{Conflicts of interest}

The authors declare that they have no conflict of interest related to the publication of this manuscript. 


\section{References}

ABELL, R., THIEME, M. L., REVENGA, C., BRYER, M., KOTTELAT, M., BOGUTSKAYA, N., COAD, B., MANDRAK, N., BALDERAS, S. C., BUSSING, W., STIASSNY, M. L. J., SKELTON, P., ALLEN, G. R., UNMACK, P., NASEKA, A., NG, R., SINDORF, N., ROBERTSON, J., ARMIJO, E., HIGGINS, J. V., HEIBEL, T. J., WIKRAMANAYAKE, E., OLSON, D., LÓPEZ, H. L., REIS, R. E., LUNDBERG, J. G., PÉREZ, M. H. S. \& PETRY, P. 2008. Freshwater Ecoregions of the World: A New Map of Biogeographic Units for Freshwater Biodiversity Conservation. BioScience 58(5):403-414.

Agostinho, A. A., GOMES, L. C. \& PELICICE, F. M. 2007. Ecologia e manejo de recursos pesqueiros em reservatórios do Brasil. EDUEM, Maringá.

ANDRIAN, I. F., SILVA, H. B. R. \& PERETTI, D. 2001. Dieta de Astyanax bimaculatus (Linnaeus, 1758) (Characiformes, Characidae), da área de influência do reservatório Corumbá, estado de Goiás, Brasil. Acta Scientiarum, Maringá 23(2): 435-440.

ARCIFA, M. S., NORTHCOTE, T. G. \& FROEHLICH, O. 1991. Interactive ecology of two cohabiting characin fishes (Astyanax fasciatus and Astyanax bimaculatus) in a eutrophic Brazilian reservoir. J. Trop. Ecol. 7(1): 257-268.

BATISTA, G. T., TARGA, M. S. \& FIDALGO, E. C. C. 2005. Banco de dados ambientais da Bacia do Rio Una, Bacia do Rio Paraíba do Sul. http://www. agro.unitau.br/una/ (último acesso em: 30/08/2017).

BIZERRIL, C. R. S. F. 1994. Análise taxonômica e biogeográfica da ictiofauna de água doce do leste brasileiro. Acta Biol. Leopoldensia 16(1): 51-80.

BIZERRIL, C. R. S. F. 1999. A ictiofauna da Bacia do Rio Paraíba do Sul, biodiversidade e padrões biogeográficos. Braz. Arch. Biol. Techn. 42(1): 233-250.

BUCKUP, P. A., MENEZES, A. A. \& GHAZZI, M. S. 2007. Catálogo das espécies de peixes de água doce do Brasil. Museu Nacional, Rio de Janeiro.

CARVAlho, E. D., CAMARGO, A. L. S. \& ZANATTA, A. S. 2010. Desempenho produtivo da tilápia do Nilo em tanques-rede numa represa pública: modelo empírico de classificação. Cienc. Rural. Santa Maria 40(7): 1616-1622.

DEVIDE, A. C. P., CASTRO, C. M., RIBEIRO, R. L. D., ABBOUD, A. C. S., PEREIRA, M. G. \& RUMJANEK, N. G. 2014. História Ambiental do Vale do Paraíba Paulista, Brasil. Revista Biociências, Taubaté 20(1): 12-29.

ESCHMEYER, W. N. \& FONG, J. D. 2017. Catalog of Fishes. http:// researcharchive.Calademy.org/research/ichthyology/catalog/fishcatmain. asp (último acesso em 02/08/2017).

ESTEVES, K. E. \& P. M. GALETTI JR. 1995. Food partitioning among some characids of a small Brazilian foodplain lake from the Paraná River basin. Environ. Biol. Fish. 42(1): 375-389.

FREITAS JUNIOR, G. \& MARSON, A. A. 2007. Estudo comparado de biogeografia - caracterização da vegetação do Vale do Paraíba paulista nos anos de 1817 e 2007. In: Seminário de Recursos Hídricos da Bacia Hidrográfica do Paraíba do Sul, 1. (SERHIDRO), IPABHI, Taubaté, p. 107-114.

FROESE, R. \& PAULY, D. 2017. FishBase. Word Wide Web electronic publication. http://www.fishbase.org/home.htm (último acesso em: 22/08/2017)

FULLER, P. L., NICO, L. G. \& WILLIAMS, J. D. 1999. Nonindigenous fishes introduced into inland waters of the United States. American Fisheries Society, Bethesda.

GODOY, M. P. 1975. Peixes do Brasil: subordem Characoidei, 1, Franciscana, Piracicaba.

HILSDORF, A.W.S. \& PETRERE JR., M. 2002. Conservação de peixes na bacia do rio Paraíba do Sul. Ciência Hoje 30(180): 62-65.
LIMA, F. C. T., BUCKUP, P. A., MENEZES, N. A., LUCENA, C. A. S., LUCENA, Z. M. S., TOLEDO-PIZA, M. \& ZANATA, A. 2007. Família Characidae insertae sedis. In Catálogo das espécies de peixes de água doce do Brasil. Museu Nacional. Rio de Janeiro, p. 64-105.

LUCENA, C. A. \& SOARES, H. G. 2016. Review of species of the Astyanax bimaculatus "caudal peduncle spot" subgroup sensu Garutti \& Langeani (Characiformes, Characidae) from the rio La Plata and rio São Francisco drainages and coastal systems of southern Brazil and Uruguay. Zootaxa 4071(1): 101-125.

MAGALHÃES, A. L. B., AMARAL, I. B., RATTON, T. F. \& BRITO, M. F. G. 2002. Ornamental exotic fishes in the Glória reservoir and Boa Vista Stream, Paraíba do Sul river basin, state of Minas Gerais, southeastern Brazil. Comunicações do Museu de Ciências e Tecnologia, Série Zoologia 15(1): $265-278$

MARENGO, J. A. \& ALVES, L. M. 2005. Tendências hidrológicas da bacia do rio Paraíba do Sul. Revista Brasileira de Meteorologia, Rio de Janeiro 20(2): 215-226

MAZZONI, R., MORAES, M., REZENDE, C. F. \& IGLESIAS-RIOS, R. 2010. Diet and feeding daily rhythm of Pimelodella lateristriga (Osteichthyes, Siluriformes) in a coastal stream from Serra do Mar, RJ. Braz. J. Biol., São Carlos 70(4): 1123-1129.

MELO, F. A. G. 2001. Revisão taxonômica das espécies do gênero Astyanax Baird \& Girard, 1854, (Teleostei: Characiformes: Characidae) da região da Serra dos Órgãos. Arquivos do Museu Nacional 59(1): 1-46.

MELO, F. C. A., MACHADO, A. C., OLIVEIRA, A. P. C., CRUZ, J. M. \& LATINI, A. O. 2006. Ictiofauna do rio Carangola, bacia do rio Paraíba do Sul, no município de Carangola, Minas Gerais, Brasil. Lundiana 7(4): 133-144.

MENEZES, N. A. 1972. Distribuição e origem da fauna de peixes de água doce das grandes bacias fluviais do Brasil. In Comissão Internacional da Bacia Paraná/Uruguai. Poluição e Piscicultura, Faculdade e Saúde Pública da USP e Instituto de Pesca, p.79-108.

MORAES, M. B., POLAZ, C. N. M., CARAMASCHI, E. P., SANTOS JÚNIOR, S. S., SOUZA, G. \& CARVALHO, F. L. 2017. Espécies Exóticas e Alóctones da Bacia do Rio Paraíba do Sul: Implicações para a Conservação. Biodiversidade Brasileira 7(1): 34-54.

NELSON, J. S., GRANDE, T. C. \& WILSON, M.V. 2016. Fishes of the World. John Wiley \& Sons, New Jersey, p.752.

OTA, R. P. 2015. Revisão taxonômica e Filogenia morfológica de Metynnis Cope, 1878 (Characiformes: Serrasalmidae). Tese de Doutorado, Instituto Nacional de Pesquisas Amazônicas, Manaus, Amazonas.

ORSI, M. L. \& AGOSTINHO, A. A. 1999. Introdução de peixes por escapes acidentais de tanques de cultivo em rios da Bacia do Rio Paraná, Brasil. Rev. Bras. Zool. 2(16): 557-560.

OYAKAWA, O. T. \& MENEZES, N. A. 2011. Checklist dos peixes de água doce do Estado de São Paulo, Brasil. Biota Neotrop.11(1): 19-31. http://www. biotaneotropica.org.br/v11n1a/pt/abstract?inventory+bn0021101a2011 (último acesso em 02/08/2017).

PAVANELLI, C. S. 2007. Família Parodontidae. In Check List of the Freshwater Fishes of South and Central America. (Reis, R. E., Kullander, S. O. \& Ferraris, C. J. J., eds.). Edipucrs, Porto Alegre, p. 4-6.

PAVANELLI, C. S. 1999. Revisão taxonômica da família Parodontidae (Ostariophysi: Characiformes). Tese de Doutorado, Universidade Federal de São Carlos, São Carlos, São Paulo.

PRADO, J. B. \& ABREU, M. M. 1995. Aspectos Geográficos do Vale do Paraíba e Município de Taubaté. Coleção Taubateana, 14. Center Gráfica e Editora Ltda, Taubaté.

REIS, R. E. 2003. Family Callichthyidae (armored catfishes). In Checklist of South and Central America (Reis, R. E., Kullander, S. O. \& Ferraris, C. J. J., eds.) Edipucrs, Porto Alegre, p. 291-309. 
REIS, R. E., ALBERT, J. S., DI DARIO, F., MINCARONE, M. M., PETRY, P. \& ROCHA, L. A. 2016. Fish biodiversity and conservation in South America. J. Fish Biol. 89(1): 12-47.

RIBEIRO, A. C. 2006. Tectonic history and the biogeography of the freshwater fishes from the coastal drainages of easter Brazil: in an example of faunal evolution associated with a divergent continental margin. Neotrop. Ichthyol., 4(3): 225-246.

SEMMENS, B. X., BUHLE, E. R., SALOMON, A. K. \& PATTENGILLSEMMENS, C. V. 2004. A hotspot of non-native marine fishes: evidence for the aquarium trade as an invasion pathway. MAR. ECOL-PROG. SER. 266(1): 239-244.
SIMBERLOFF, D. 2003. How Much Information on Population Biology Is Needed to Manage Introduced Species? Conserv. Biol. 17(1): 83-92.

TARGA, M. S. 2009. Estudo Hidrológico da Bacia do Rio Una: Subsídios para estabelecimento de plano de macrodrenagem no Vale do Paraíba do Sul - SP. Programa de Pós-Graduação em Ciências Ambientais - Unitau, Taubaté, p.1-14.

TEIXEIRA, T. P., TERRA, B. F., ESTILANO, E. O., GARCIA, D., PINTO, B. C. T. \& ARAÚJO, F. G. 2004. Distribuição da ictiofauna em locais impactados no rio Paraíba do Sul. Rev. Univ. Rural, Sér. Ci. Vida. Seropédica, Rio de Janeiro, 2(2): 167-174.

VIEIRA, F.; RODRIGUES, R. R. 2010. A fauna de peixes dos afluentes do rio Paraíba do Sul no estado de Minas Gerais. MG-Biota 3(1): p. 5-23.

Received: 04/06/2018

Accepted: $23 / 07 / 2018$

Published online: $30 / 08 / 2018$ 